\title{
Long Term Hydrological Changes in the Apalachicola River, Florida
}

\author{
Sanjeev Joshi* \\ Grazing land Research Laboratory, USDA-ARS, USA
}

Submission: March 20, 2019; Published: June 07, 2019

*Corresponding author: Sanjeev Joshi, Post-doctoral Research Associate, Grazingland Research Laboratory, USDA-ARS, El Reno, Oklahoma; USA

\begin{abstract}
This short review extensively synthesizes information available in the long-term hydrologic changes experienced by the Apalachicola River in Florida, throughout its reach. Hydrologic changes in this river were induced by human interference along the river reach. The changes mostly include spatiotemporal alterations in the water levels and discharge regimes of the river. These changes have specifically reduced variability in its stages and flow regimes at several locations along its reach. The reduced variability of these important hydrological components could impact the adjoining floodplain ecosystem negatively. Therefore, ongoing river restoration efforts should focus on mimicking the natural historical hydrology in the river.
\end{abstract}

Keywords: Hydrologic changes; Water levels; Discharge; Apalachicola river

\section{Introduction}

Numerous rivers around the world have experienced long term artificial changes in their hydrology [1,2]. These changes are induced by engineering structures (such as dams and reservoirs) [1-3], navigation [4,5], waste disposal [6], channelization, and construction of levees and canals [7]; and have altered the river floodplain ecosystems to a level of threatening their biodiversity $[8,9]$. Alternations in river floodplain ecosystems may include changes in forest community structure and successional processes [10], decrease in establishment and growth of floodplain trees [11,12], mortality of overstorey trees [13], and extensive shifts from herbaceous to woody communities [14]. Hydrologic changes can also impact sediment processes in rivers adversely which can further prove costly to the formation, development and sustainability of river deltas [15-17].

Hydrological changes in rivers mainly include alterations (mostly decrease) in their natural discharge (flow) regimes and stages (water levels) [2]. River-floodplain ecosystems depend substantially on flood pulse, defined as the timing, depth, duration and frequency of river floods $[18,19]$. Higher variability and predictability in flood-pulse is necessary for sustainable and dynamic river-floodplain ecosystems [18,19]. However, rivers around the world are being subjected to artificial control more recently which has brought about reduction in their peak discharge [20] and frequency and duration of their floods [18]. Similarly, reduction in river stages due to human induced changes in rivers have also been documented previously [21-23].
The Apalachicola River (described extensively in the "Study Area" section below) in Florida has also experienced long term hydrologic change due to anthropogenic interferences. Previous studies have quantified long term stage and discharge changes in the river [21,24-26]; however, information available in this regard has not been synthesized properly till date. Such a synthesis can help in river management and restoration plans in terms of mimicking the natural stage and discharge variability in the river. Therefore, this study attempts to delve deeper into long term hydrological changes in the Apalachicola River. Current and historical river stages and discharge have been compared and any such information available on peer reviewed journals and relevant federal reports have been synthesized.

\section{Study Area}

The Apalachicola River (Figure 1) lies in Florida as a major alluvial river on the state's coastal plain. It is formed because of the confluence of the Flint and Chattahoochee Rivers, very close to the state line between Florida and Georgia, near the town of Chattahoochee, Florida [27]. At its mouth, the river drains into an inlet of the Gulf of Mexico called Apalachicola Bay, at Apalachicola [27]. This river is $171 \mathrm{~km}$ long and has a mean annual discharge of $\sim 630 \mathrm{~m}^{3} / \mathrm{s}$ [28]. It experiences extensive seasonal variability in daily discharge ranging approximately from $250 \mathrm{~m}^{3} / \mathrm{s}$ (low) in late summer and/or fall (July - November) to $3000 \mathrm{~m}^{3} / \mathrm{s}$ in late winter and/or early spring (January - April) [24,29]. However, the variability in discharge has reduced over time due to excessive human intervention in the river [21]. 


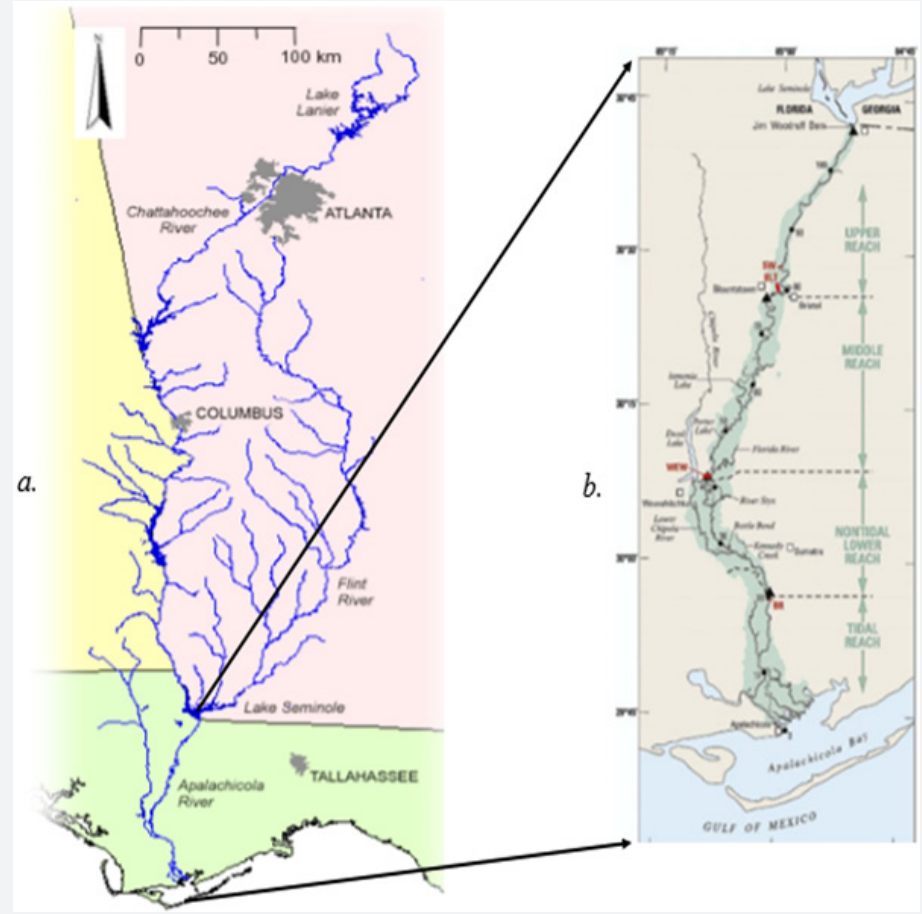

Figure 1: Part (a.) is the map of the Apalachicola River with reference to the Apalachicola-Chattahoochee-Flint (ACF) River Basin in part (a.) (Kept from Smith [29]), while part (b.) is the map of Apalachicola River specifically categorized into different Gage stations and four reaches: Upper, Middle, Non-tidal, and Tidal (kept from Stallins et al. [3]).
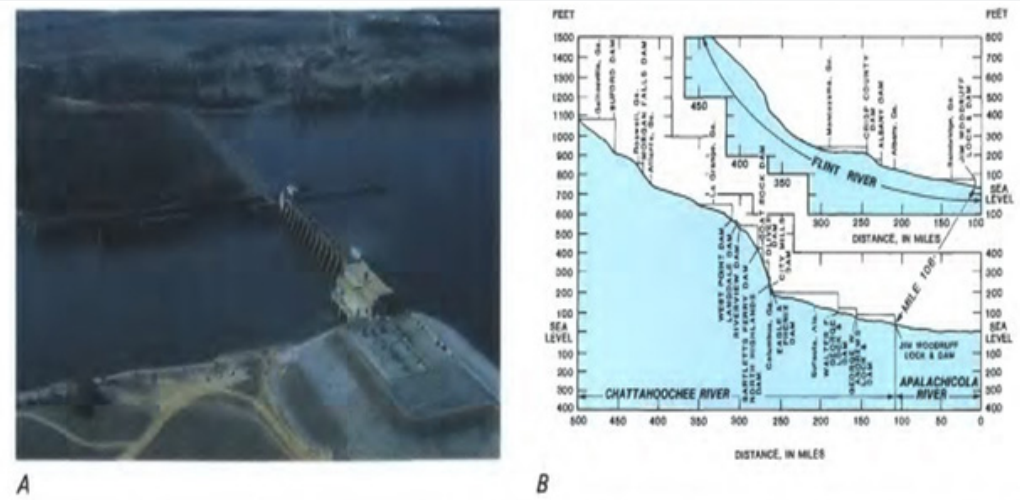

\section{B}
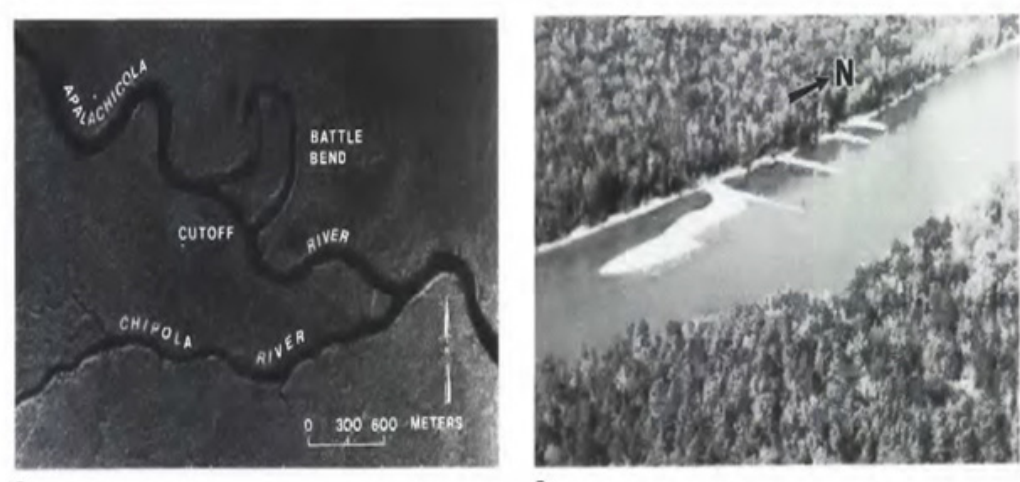

D

Figure 2: Anthropogenic changes in the Apalachicola River.
(A) the Jim Woodruff Lock and Dam,
(B) elevations for all the dams in the Apalachicola-Chattahoochee-Flint (ACF) River Basin,
(C) specific example of meander cutoffs in the Apalachicola River, and
(D) river training dikes at $\sim 160$ river kilometers (rk) in the Apalachicola River (figure kept from Elder et al. [24]). 
Some studies have reported that flooding is important along the river because river flooding supports largest floodplain forests in Florida [26]. Floodplain forests of the river include unique ravines, karstic caves, longleaf savannas, pine woodlands and seepage bogs [30]. These forests are dominated in majority by bottomland hardwoods [30]. Floodplain forests of the river are covered by water from the river during floods which usually occur in late winter to early springs [31]. More recently floodplain forests of the river have become compositionally drier with fewer indicator species due to human induced changes in the river stages and flows [3].

\section{History of Artificial Changes in the Apalachicola River}

The Apalachicola River has experienced several anthropogenic influences till date. The whole ApalachicolaChattahoochee-Flint (ACF) River Basin consists of 16 dams in total, out of which the Jim Woodruff Dam specifically lies in the Apalachicola River [24]. In 1950, the United States Army Corps of Engineers (USACE) started to construct the Jim Woodruff Dam (Figure 2A) at the confluence of the Chattahoochee and Flint Rivers, where the river starts [24]. The dam was first opened in Hydrological Changes in the Apalachicola River
February 1957 after completion of its reservoir, Lake Seminole $[24,29]$. Several other dams with varying elevations were later constructed further downstream in the ACF river basin (Figure 2B) [24]. In addition, the river has been dredged several times $[24,29]$. Dredging was sporadic before 1950s, but after the Jim Woodruff Dam began to operate, USACE began to maintain $30 \mathrm{~m}$ wide and $2.7 \mathrm{~m}$ deep channel on a regular basis $[24,29]$. Initially the dredged material (as much as $800,000 \mathrm{~m}^{3} /$ year) was placed on the Apalachicola River floodplain which caused high proportion of tree mortality [29,32]. However, disposal sites within the main channel are searched, evaluated and utilized for the dredged material more recently $[29,32]$.

The river has faced a few more anthropogenic changes such as water storage and release by the Jim Woodruff Dam during high and low flows respectively [29]; meander cut offs due to which channel got shortened by $\sim 3 \mathrm{~km}$ (Figure 2C) [24,29]; installation of groins (29 sets) and river training dikes (Figure 2D) [24], and the periodic removal of rocks from the bed $[28,29]$. In addition to these anthropogenic influences, the river also goes across five bridges namely: Victory, Rail, Dewey M. Johnson, Trammell, Rail and John Gorrie Memorial Bridges [33].

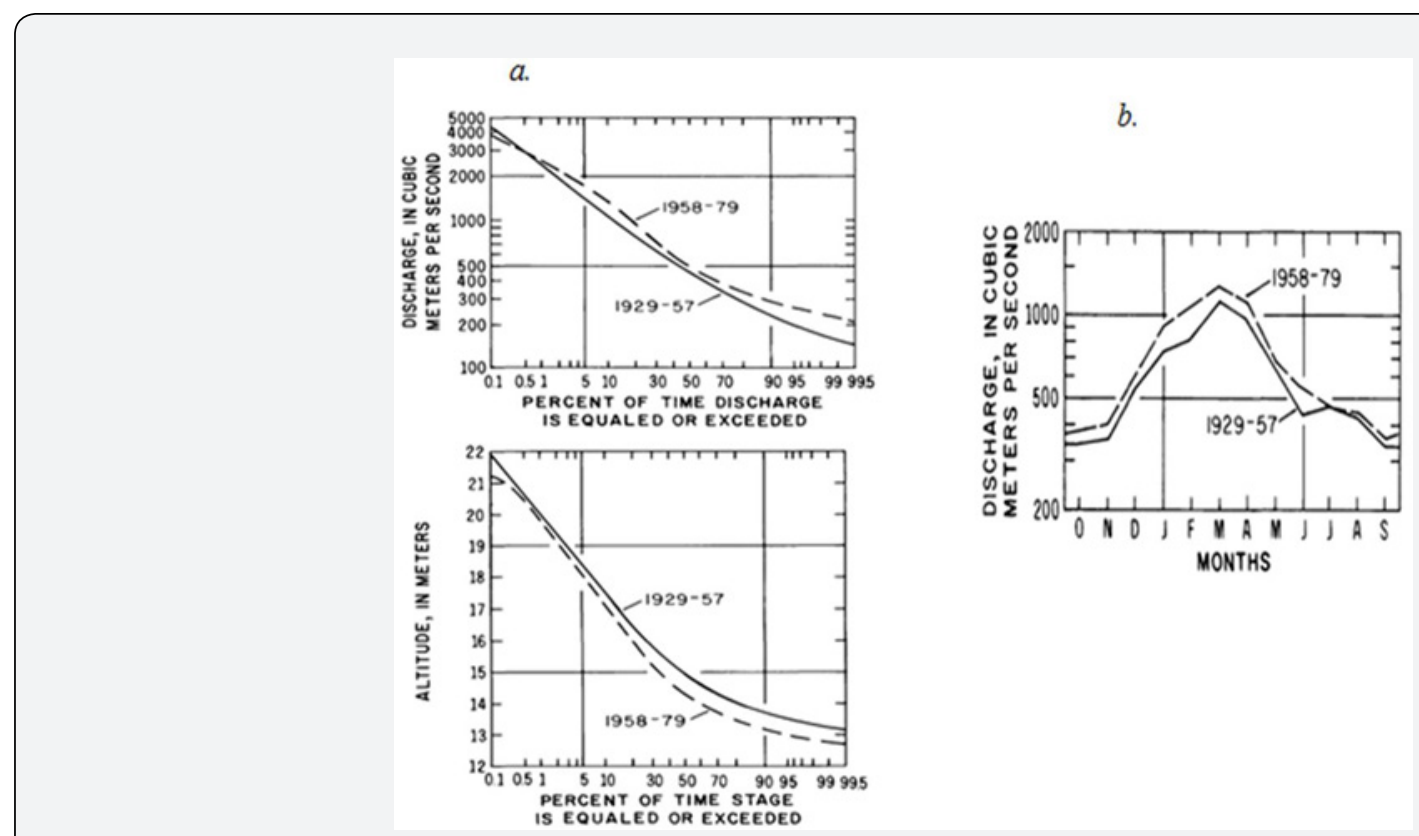

Figure 3: (a.) Flow (upper) and stage (lower) exceedance curves of the Apalachicola River at Chattahoochee during pre- (1929-1957) and post-dam periods (1958-1979);

(b.) Average monthly flows in the Apalachicola River at Chattahoochee (taken from Leitman et al. [32]).

The Apalachicola River have been experiencing anthropogenic changes induced by sporadic dredging before 1950s which further increased considerably from mid-1950s after Jim Woodruff Dam construction [29]. However, systematic investigation on the nature of these changes and their impacts on water quality, stage and discharge of the river started much later in 1980s. Leitman et al. [32] and Elder et al. [24] were pioneer studies in this regard, both carried out by the United States Geological Survey (USGS). Leitman et al. (1983) compared the pre- (1929-1957) and post- (1958-1979) dam river stages and discharge regimes at two upstream gaging stations (Chattahoochee and Blountstown) in the river. They observed higher pre-dam river stages at both stations and lower annual and monthly flows at uppermost gaging station at Chattahoochee (they could not conclude anything about preand post-dam flows further down at Blountstown) (deduced from exceedance curves in Figure 3 - note that this figure only informs about Chattahoochee gage, please check the report for 
similar figure on Blountstown gage). They further argued that climatic changes were probably responsible for higher post-dam river flows, while lower post-dam river stages were induced by physical changes in the river channel. Similar observations were made by Elder et al. [24] that the artificial changes impacted river stages more than river flows especially in the upper reaches of the river and that the effects of the changes in river flows are not noticeable.

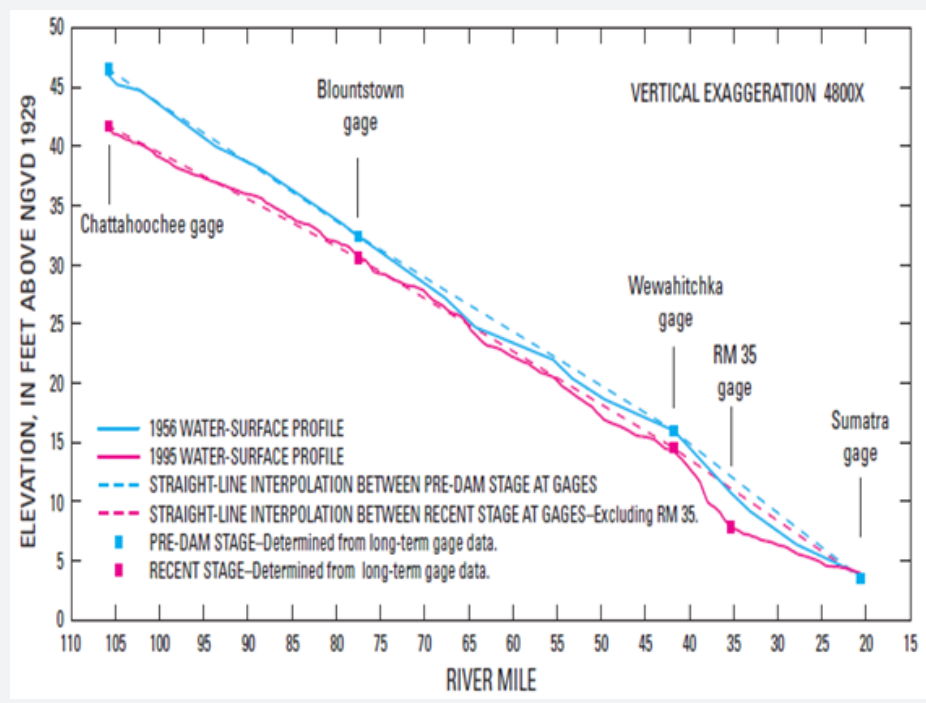

Figure 4: Comparison of pre- and post-dam water-surface profiles and average river stage at several gage stations along the Apalachicola River (taken from Light et al. [21]).

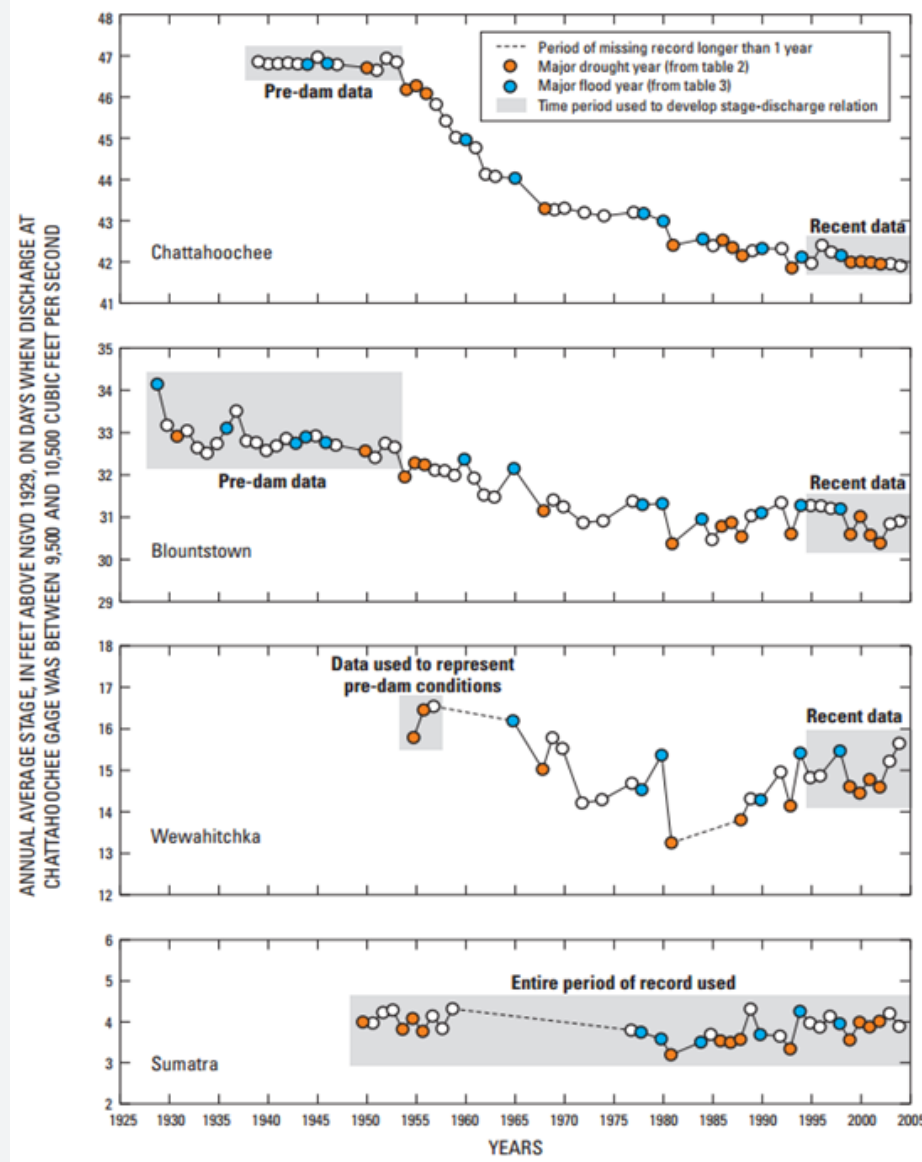

Figure 5: Yearly trend of river stages at four different locations [having United States Geological Survey gages) in the river. The flow conditions during the year have been separated by blue (flood year), brown (dry year) or while (normal year) dots. Annual analysis was based on climate years (April 1-March 31) (taken from Light et al. [21]). 
Hydrologic records of the Apalachicola River were also analyzed in depth by another USGS report, Light et al. [21] (Figures 4 \& 5). This report provides an extensive examination of past (pre-dam) and present (post-dam) water levels at four gaging stations (Chattahoochee, Blounstown, Wewahitchka and Sumatra) systematically from upstream to downstream covering the whole river reach. They found lower water surface profile in 1995 (post-dam) than in 1956 (just before dam construction) (Figure 4). They further observed that the pre-dam to post-dam period river stage (RS) declines were evident in the upstream parts of the river at Chattahoochee and Blountstown gaging stations, while, not noticeable in the downstream parts at
Wewahitchka and Sumatra (Figure 5). Furthermore, highest water level declines in the post-dam period were observed during low flows which were also observed by Darst \& Light [31]. Darst \& Light [31] further deduced that water level decline in the low flows was highest in the upstream parts of the river; the decline gets reduced in the middle and lower reach (Figure 6). They pointed out that the lowest decline in river stages of low flows could be observed at lowermost parts of the river very close to the Apalachicola Bay (Figure 6). They also deduced that water levels had declined more due to channel erosion as compared to reduced flows in the upstream parts of the river (Figure 6).

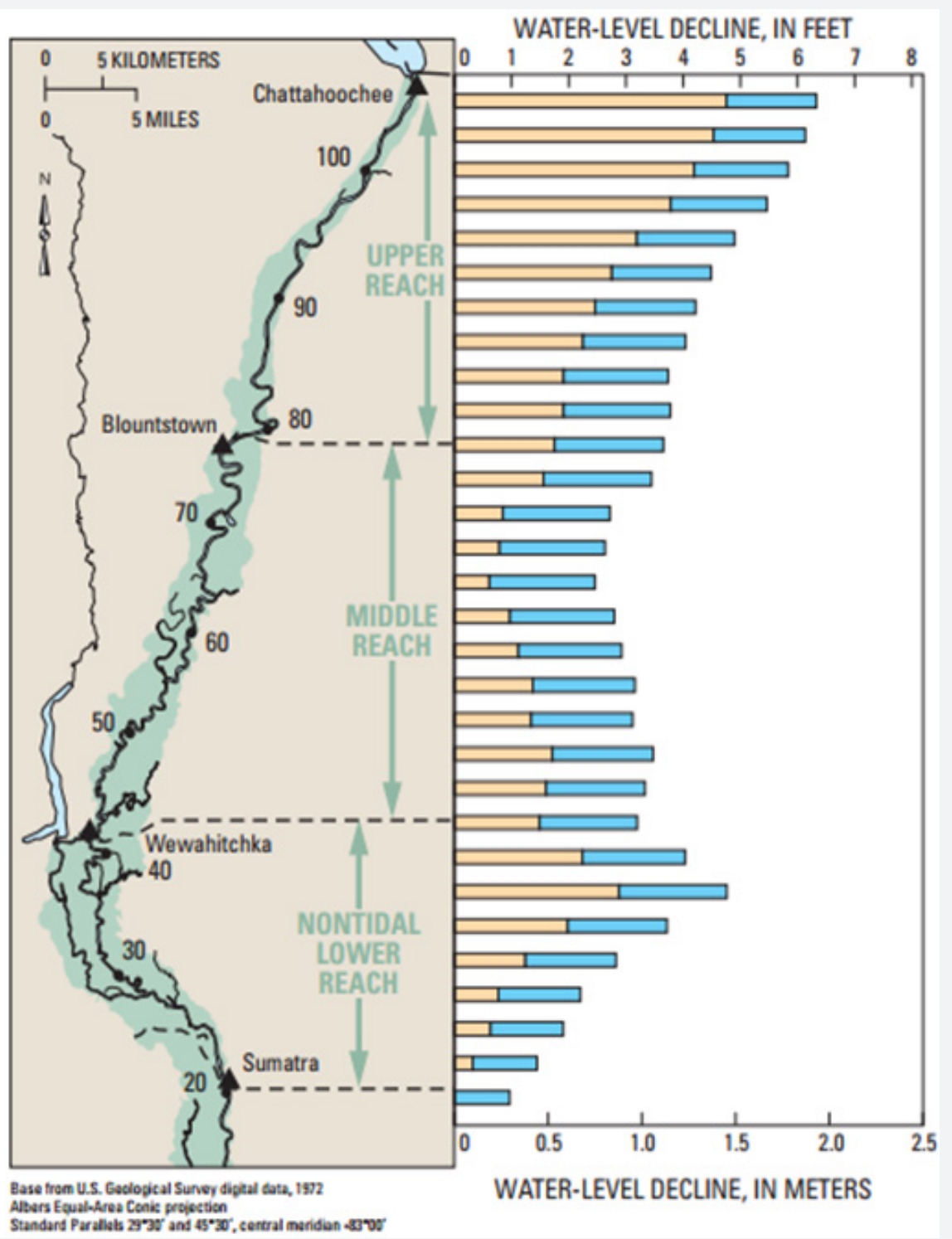

Figure 6: Long term water-level decline along the Apalachicola River during drought conditions (defined by lowest $10 \%$ of the flows) during 1929-2004. Brown color in the bars denote water level loss due to channel erosion, while, blue colors represent water level decline caused by decreased flow in the river (taken from Darst and Light [31]).

Most recently, Smith et al. [26] examined the hydrological shifts in the Apalachicola River at Chattahoochee and Blountstown gages and overall impact of the shifts in river modification (Figure 7). Smith et al. found lowering for long term 5-year moving averages of stage and discharge at the Chattahoochee gage (Figure 7a). As suggested earlier by Leitman et al. [32] and Elder et al. [24] the lowering was evident in stages while not so much in the river discharge (Figure 7a). Similarly, 
abrupt changes were observed in the number of reversals per year between daily average stage values (Figure 7b) at the Chattahoochee gage and average rise and fall rates of river stages at the Blountstown gage (Figure 7c). The number of reversals per year increased in the post dam period in which the rise/fall rates were more variable. Smith et al. [26] and all the studies support the argument about reduced variability in both stages and flow of the Apalachicola River.
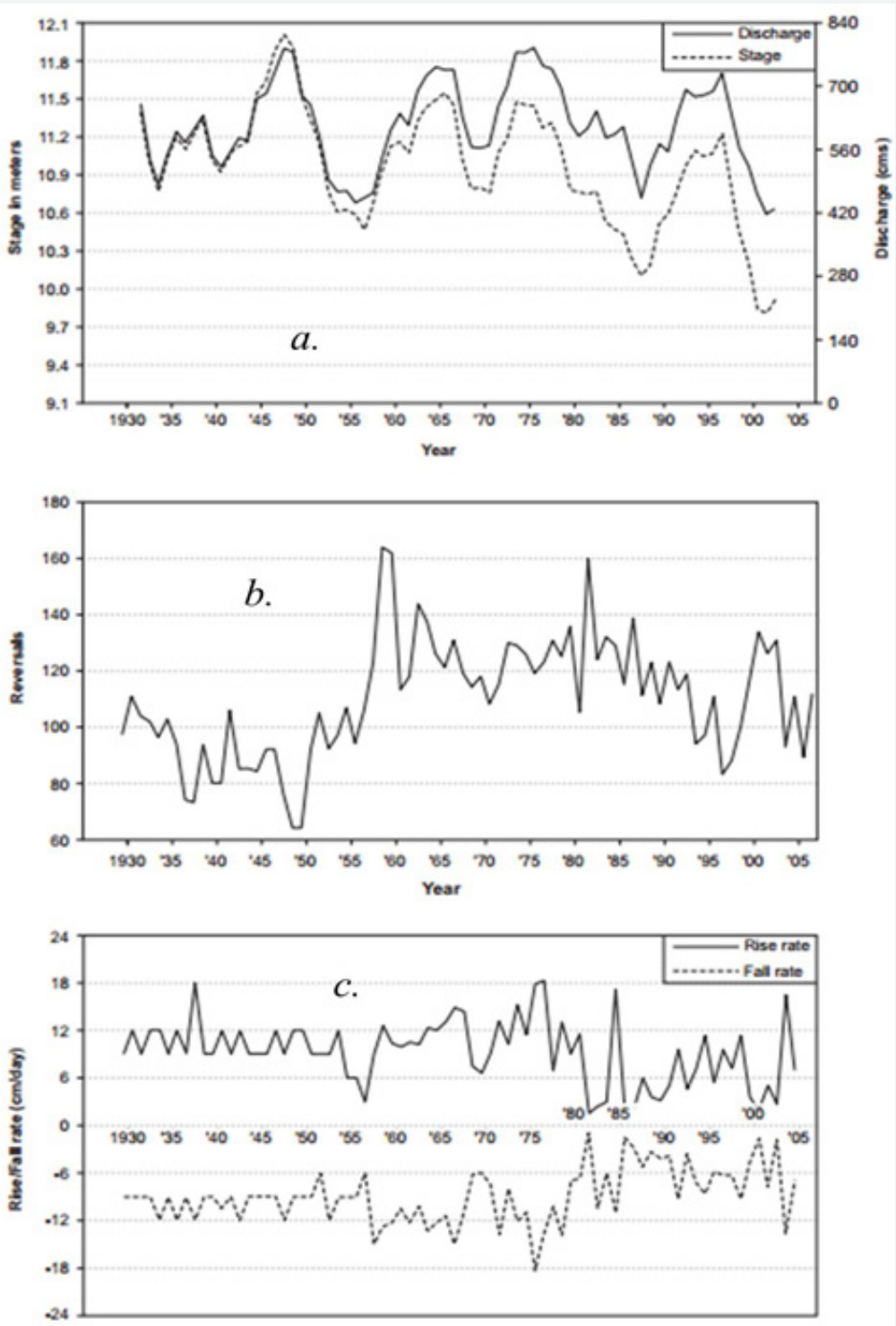

Figure 7: (a.) Five-year moving average of mean annual river stage (RS) $(\mathrm{m})$ and mean annual river discharge (cms);

(b.) number of days per year in which average daily RS reverses between rise and fall;

(c.) annual average rate of rise and fall of river stages at the Blountstown gage $(\mathrm{cm} / \mathrm{day})$.

Note: (a.) and (b.) were analyzed at Chattahoochee gage, while, (c.) was analyzed at Blountstown gage. All (a.), (b.) and (c.) were for the Apalachicola River (taken from Smith et al. [26]).

\section{Discussion}

The argument of Leitman et al. [32] and Elder et al. [24] regarding little impact of dam effect on river flows seems questionable because dams can regulate river flows. Thus, higher river flows in the post-dam period could be because of pre-selected discharge regimes which were not possible to be selected during the pre-dam periods. Further, all studies claim that Apalachicola River has reduced hydro-period over time especially after the dam was built along the river-reach.
The river has experienced reduction in peak flows and peak river stages. Specifically, upper reach of the river has lost more water than the lowermost part of the river. Such shifts in hydrologic regimes occurred because of anthropogenic changes in the watershed. These changes may have negative impacts in sediment and ecological processes along the river. Similar shifts in geomorphology and sediment transport (both bed and suspended load) have been noted for the Lowermost Mississippi River (downstream from the Old River Control Structures [3436]. 


\section{Conclusion}

Hydrologic changes basically include alterations in stages and flows of a river. Anthropogenic interference in the Apalachicola River was subtle before 1950s. However, the construction of dam in the uppermost part of the river in mid-1950s marked the increase in human induced hydrological changes in the river. River stages have declined throughout the river reach due to channel changes. Although, the river flows seem to have increased in the post-dam period, their variability has been reduced due to river regulation by the dam at the uppermost part of the river. The reduced variability in river stages and flows has reportedly caused various problems to the river such as saltwater intrusion, sediment loss, floodplain and aquatic habitat degradation. Ongoing river restoration efforts should focus on the goal of mimicking the natural historical hydrology in the river.

\section{Acknowledgement}

This study was part of a semester project in the Deltaic Geology course offered in the Department of Geography and Anthropology, Louisiana State University during spring 2016. The author would like to thank Dr. Samuel Bentley (the course instructor) for his critical inputs and suggestion as the direct supervisor in the study. The author is solely responsible for the statements, findings, and conclusions of this study.

\section{References}

1. Sparks RE (1995) Need for ecosystem management of large rivers and their floodplains. BioScience 45(3): 168-182.

2. Poff NL, Allan JD, Bain MB, Karr JR, Prestegaard KL, et al. (1997) The Natural Flow Regime. BioScience 47(11): 769-784.

3. Stallins JA, Nesius M, Smith M, Watson K (2010) Biogeomorphic characterization of floodplain forest change in response to reduced flows along the Apalachicola River, Florida. River research and applications 26(3): 242-260.

4. Ferguson HB (1940) History of the Improvement of the Lower Mississippi River for Navigation and Flood Control, 1932-1939.

5. Winkley BR, Brooks JH (1980) Navigation and Flood Control through Geometric Alignment. Potamology Investigation Report 300-3. Potamology Section, Hydraulics Branch. US Army Corps of Engineers, Vicksburg District.

6. Hettler J, Irion G, Lehmann B (1997) Environmental impact of mining waste disposal on a tropical lowland river system: a case study on the Ok Tedi Mine, Papua New Guinea. Mineralium Deposita 32(3): 280291.

7. Hupp CR, Pierce AR, Noe GB (2009) Floodplain geomorphic processes and environmental impacts of human alteration along coastal plain rivers, USA. Wetlands 29(2): 413-429.

8. Bendix J, Hupp CR (2000) Hydrological and geomorphological impacts on riparian plant communities. Hydrological processes 14(16): 29772990.

9. Voeroesmarty CJ, McIntyre PB, Gessner MO, Dudgeon D, Prusevich A, et al. (2010) Global threats to human water security and river biodiversity. Nature 468(7321), 334-334.

10. Palta MM, Richardson EA, Sharitz RR (2003) Effects of altered flow regimes on floodplain forest processes in the Savannah River basin.
11. Reily PW, Johnson WC (1982) The effects of altered hydrologic regime on tree growth along the Missouri River in North Dakota. Canadian Journal of Botany 60(11): 2410-2423.

12. Polzin ML, Rood S (2000) Effects of damming and flow stabilization on riparian processes and black cottonwoods along the Kootenay River. Rivers 7(3): 221-232.

13. Wilder T, Roberts T (2005) A comparison of tree species composition in bottomland hardwoods adjacent to channelized and unchannelized rivers in western Tennessee. Ecology and management of bottomland hardwood systems: the state of our understanding, pp. 445-461.

14. Weller MW (1989) Plant and water-level dynamics in an east Texas shrub/hardwood bottomland wetland. Wetlands 9(1): 73-88.

15. Gagliano SM, Meyer-Arendt KJ, Wicker KM (1981) Land loss in the Mississippi River deltaic plain. GCAGS Transactions 31(1981): 295-300.

16. Kesel RH (2003) Human modifications to the sediment regime of the Lower Mississippi River flood plain. Geomorphology 56(3-4): 325-334.

17. Meade RH, Moody JA (2010) Causes for the decline of suspended-sediment discharge in the Mississippi River system, 1940-2007. Hydrological Processes 24(1): 35-49.

18. Junk WJ, Bayley PB, Sparks RE (1989) The flood pulse concept in river-floodplain systems. Canadian special publication of fisheries and aquatic sciences 106(1): 110-127.

19. Day JW, Pont D, Hensel PF, Ibañez C (1995) Impacts of sea-level rise on deltas in the Gulf of Mexico and the Mediterranean: the importance of pulsing events to sustainability. Estuaries 18(4): 636-647.

20. Williams GP, Wolman MG (1984) Downstream effects of dams on alluvial rivers. USGS Professional Paper Series no. 1286. p. 83.

21. Light HM, Vincent KR, Darst MR, Price FD (2006) Water-level decline in theApalachicola River, Florida, from 1954 to 2004, and effects on floodplain habitats. U. S. Geological Survey Scientific Investigations Report 2006-5173, pp.1-62.

22. Pinter N, Ickes BS, Wlosinski JH, van der Ploeg RR (2006) Trends in flood stages: Contrasting results from the Mississippi and Rhine River systems. Journal of Hydrology 331(3-4): 554-566.

23. Jemberie AA, Pinter N, Remo JWF (2008) Hydrologic history of the Mississippi and Lower Missouri Rivers based upon a refined specific-gauge approach. Hydrological Processes 22(22): 4436-4447.

24. Elder JF, Flagg SD, Mattraw HC (1988) Hydrology and ecology of the Apalachicola River, Florida: a summary of the River Quality Assessment. U. S. Geological Survey Water-Supply Paper 2196-D.

25. Schneider RL, Martin NE, Sharitz RR (1989) Impact of dam operation on hydrology and associated floodplain forests of southeastern rivers. In: Sharitz RR, Gibbons JW (Eds.), Freshwater wetlands and wildlife. United States Department of Energy Symposium Series 61, CONF8603101, United States Department of Energy Office of Scientific and Technical Information, Oak Ridge, TN, pp. 1113-1121.

26. Smith MC, Stallins JA, Maxwell JT, Dyke CV (2013) Hydrological shifts and tree growth responses to river modification along the Apalachicola River, Florida. Physical Geography 34(6): 491-511.

27. Frick EA, Hippe DJ, Buell GR, Couch CA, Hopkins EH, et al. (1998) Water quality in the Apalachicola-Chattahoochee-Flint river basin, Georgia, Alabama, and Florida, 1992-95. U. S. Geological Survey Circular 1164.

28. Light HM, Darst MR, Grubbs JW (1998) Aquatic habitats in relation to river flow in the Apalachicola River floodplain, Florida. U. S. Geological Survey Professional Paper 1594, pp.1-90.

29. Smith MC (2007) Long-Term Change in Hydrology, Tree Growth, and Forest Composition along the Apalachicola River. MS Thesis. Florida State University, p. 86. 
30. Stein BA, Kutner LS (2000) Precious Heritage: The Status of Biodiversity in the United States: The Status of Biodiversity in the United States, Oxford University Press, USA

31. Darst MR, Light HM (2008) Drier Forest Composition Associated with Hydrologic Change in the Apalachicola River Floodplain, Florida: U.S Geological Survey Scientific Investigations Report 2008-5062, pp. 1-89.

32. Leitman HM, Sohm JE, Franklin MA (1983) Wetland hydrology and tree distribution of the Apalachicola River flood plain, Florida. U.S. Geological Survey Water-Supply Paper 2196-A.

33. Plotkin S (2013) Outstanding Bridges of Florida. A photograph collection. p. 33.

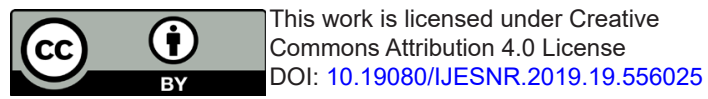

34. Joshi S, Xu YJ (2015) Assessment of suspended sand availability under different flow conditions of the Lowermost Mississippi River at Tarbert Landing during 1973-2013. Water 7(12): 7022-7044.

35. Joshi S, Xu YJ (2017b) Bedload and Suspended Load Transport in the $140-\mathrm{km}$ Reach Downstream of the Mississippi River Avulsion to the Atchafalaya River. Water 9(9): 716

36. Joshi S, Jun XY (2018) Recent changes in channel morphology of a highly engineered alluvial river-the Lower Mississippi River. Physical Geography 39(2): 140-165.

Your next submission with Juniper Publishers will reach you the below assets

- Quality Editorial service

- Swift Peer Review

- Reprints availability

- E-prints Service

- Manuscript Podcast for convenient understanding

- Global attainment for your research

- Manuscript accessibility in different formats ( Pdf, E-pub, Full Text, Audio)

- Unceasing customer service

Track the below URL for one-step submission https://juniperpublishers.com/online-submission.php 